\title{
Analisis Faktor-Faktor yang Berhubungan Dengan Status fungsional pada Pasien Osteoartritis di RSUD Raden Mattaher Jambi Tahun 2018
}

\author{
Dewi Masyitah \\ Jurusan Keperawatan Politeknik Kesehatan Kemenkes Jambi \\ Correspondence email: dewi_mahyudi@yahoo.co.id
}

\begin{abstract}
Abstrak. Osteoarthritis is a degenerative and progressive disease characterized by joint abrasion and formation irregular bone on the surface of the joints. Osteoarthritis causes pain and limits joint mobility. Patients have limitation in functional status that interferes with daily life activities. The purpose of this study was to identify factors related to functional status in patients with osteoarthritis. This research used a cross-sectional design involving 70 patients with osteoarthritis at Raden Mattaher Hospital. Sampel were obtained with purposive sampling and data analysis using chi-square test. The results showed that there was a significant association between pain, age, body mass index and family support with functional status. Joint exercises, pain management and strengthening the role of the family to improve the functional status patients with osteoarthritis.
\end{abstract}

Keyword: Functional status; Osteoarthritis

\section{PENDAHULUAN}

Osteoarthritis menurut American College of Rheumatology merupakan sekelompok kondisi heterogen yang mengarah kepada tanda dan gejala sendi. Osteoarthritis merupakan penyakit degeneratif dan progresif ditandai oleh adanya abrasi rawan sendi dan adanya pembentukan tulang baru yang irregular pada permukaan persendian. Nyeri menjadi gejala utama terbesar pada sendi yang mengalami osteoarthritis dan disabilitas pada pasien sehingga mengganggu aktifitas sehari-hari dari tingkat yang ringan sampai berat (Pratiwi, 2015).

Insidensi osteoarthritis meningkat seiring dengan usia dengan adanya bukti pada gambaran fotopolos. Insidensi osteoartritis di Amerika pada usia 18-24 tahun, 7\% laki-laki dan 2\% perempuan menggambarkan osteoarthritis pada tangan. Pada usia 55-64 tahun, 28\% laki-laki dan perempuan terkena osteoarthritis lutut dan 23\% osteoarthritis panggul. Pada usia antara 65-74 tahun, 39\% laki-laki dan perempuan menggambarkan osteoarthritis pada lutut dan 23\% menggambarkan osteoarthritis pada panggul. Pada usia diatas 75 tahun, sekitar $100 \%$ laki-laki dan perempuan mempunyai gejala-gejala osteoartritis (Arissa, 2012). Data di Indonesia, prevalensi osteoartritis mencapai $5 \%$ pada usia <40 tahun, 30\% pada usia 40-60 tahun, dan $65 \%$ pada usia $>61$ tahun (Imayati, 2011).

Berat badan yang berlebih merupakan suatu kondisi yang erat kaitannya dengan peningkatan risiko untuk timbulnya osteoartritis terutama pada sendi penopang tubuh, seperti lutut, baik pada laki - laki maupun perempuan (Soeroso, 2009). Obesitas akan meningkatkan stress pada sendi penopang tubuh sehingga akan memberikan rasa nyeri. Penelitian menunjukkan bahwa seseorang dengan indeks masa tubuh katagori overweight memiliki risiko besar untuk terkena osteoartritis dibandingkan dengan orang yang memiliki indeks massa tubuh normal (Koentjoro, (2010).
Osteoartritis bersifat kronis dan progresif, sangat sering menyebabkan gangguan aktifitas yang dialami oleh hampir $80 \%$ penderitanya (McKay, Prapavessis \& Doherty, 2012). Status fungsional individu dapat terganggu dengan adanya bagian tubuh yang mengalami cidera atau kerusakan akibat dari banyak faktor yang salah satunya adalah suatu kondisi karena dari proses degenerasi pada tubuh individu tersebut. Status fungsional adalah suatu konsep mengenai kemampuan melakukan self-care, self-maintenance, dan aktivitas fisik (Wilkinson, 2011 dalam Ropyanto, 2014).

Osteoarthritis adalah penyakit yang menyebabkan rasa sakit dan keterbatasan fungsional yang mengganggu aktivitas kehidupan sehari-hari : seperti makan, mandi, eliminasi dan perawatan diri lainnya (McKay, Prapavessis \& Doherty, 2012). Osteoarthritis menyebabkan rasa sakit dan membatasi mobilitas sendi menyebabkan gangguan berdiri dan berjalan. Penderita osteoarthritis akan mengalami penurunan keseimbangan yang dapat menyebabkan gangguan postural (Lee, Kim, Chung \& Lee, 2017). Seseorang dengan osteoartritis lutut memiliki risiko lebih besar untuk terjatuh, dan telah dilaporkan bahwa sekitar $30 \%$ dari populasi lansia berusia 65 dan lebih tua mengalami kejadian jatuh setidaknya sekali setahun (Hale, Waters \& Herbison, 2012).

Berdasarkan hasil studi pendahuluan di Poliklinik Syaraf RSUD Raden Mattaher Jambi didapatkan bahwa kasus osteoarthritis termasuk ke dalam sepuluh penyakit terbanyak setiap tahunnya. Pada tahun 2015 jumlah kunjungan pasien sebanyak 988 kali dengan 154 kasus baru. Tahun 2016 jumlah kunjungan pasien sebanyak 458 kali dengan 39 kasus baru. Tahun 2017 jumlah kunjungan sebanyak 439 kali dengan 67 kasus baru. Selain itu peneliti juga melakukan wawancara pada lima orang pasien osteoartritis. Dari hasil wawancara pada lima orang pasien tersebut, didapatkan hasil bahwa faktor yang paling mengganggu mereka dalam 
beraktifitas sehari-hari adalah rasa nyeri. Sebanyak empat orang termasuk berusia lansia dan memiliki indeks massa tubuh termasuk katagori berat badan berlebih. Semua pasien mengatakan motivasinya menjalani pengobatan atas kesadaran sendiri dan mendapatkan dukungan dari keluarga.

\section{METODE}

Penelitian ini merupakan penelitian analitik korelatif dengan menggunakan desain cross-sectional yang bertujuan untuk mengindentifikasi faktor-faktor yang berhubungan dengan status fungsional pada pasien osteoartritis. Populasi pada penelitian ini adalah pasien osteoartritis yang berobat di Poli Syaraf RSUD Raden Mattaher Jambi dengan jumlah sampel sebanyak 70 responden diperoleh secara purposive sampling.

\section{HASIL DAN PEMBAHASAN \\ Analisis Univariat}

Hasil analisis univariat karakteristik responden berdasarkan tingkat nyeri dapat dilihat pada tabel 1 berikut ini:

Tabel 1. Distribusi Karakteristik Responden Berdasarkan Tingkat Nyeri Di Poliklinik Syaraf RSUD Raden Mattaher Jambi Tahun $2018(n=70)$

\begin{tabular}{|c|c|c|}
\hline Nyeri & Frekuensi & Persentase (\%) \\
\hline Ringan & 9 & $12,9 \%$ \\
\hline Sedang & 61 & $87,1 \%$ \\
\hline Jumlah & 70 & $100 \%$ \\
\hline
\end{tabular}

Data tabel 1 menunjukkan bahwa sebagian besar nyeri yang dialami oleh responden termasuk katagori nyeri sedang $(87 \%)$.

Hasil analisis univariat karakteristik responden berdasarkan umur dapat dilihat pada tabel 2 berikut ini:

Tabel 2. Distribusi Karakteristik Responden Berdasarkan Umur Di Poliklinik Syaraf RSUD Raden Mattaher Jambi 2018 $(n=70)$

\begin{tabular}{ccc}
\hline Umur & Frekuensi & Persentase (\%) \\
\hline Dewasa Awal & 7 & $10 \%$ \\
Dewasa Menengah & 40 & $57,1 \%$ \\
Dewasa Lanjut & 23 & $32,9 \%$ \\
Jumlah & 70 & $100 \%$ \\
\hline
\end{tabular}

Data tabel 2 menunjukkan bahwa lebih dari separuh umur responden termasuk dalam rentang usia dewasa menengah $(57,1 \%)$.

Hasil analisis univariat karakteristik responden berdasarkan indeks massa tubuh dapat dilihat pada tabel 3 berikut ini:
Tabel 3. Distribusi Karakteristik Responden Berdasarkan Indeks Massa Tubuh Di Poliklinik Syaraf RSUD Raden Mattaher Jambi Tahun 2018 (n=70)

\begin{tabular}{lcc}
\hline \multicolumn{1}{c}{ Indeks Massa Tubuh } & Frekuensi & Persentase (\%) \\
\hline Berat Badan Di Bawah & 2 & $2,9 \%$ \\
Normal & 29 & $41,4 \%$ \\
Normal & 15 & $21,4 \%$ \\
Kelebihan Berat Badan & 24 & $34,3 \%$ \\
Obesitas & 70 & $100 \%$ \\
\multicolumn{2}{c}{ Jumlah } &
\end{tabular}

Data tabel 3 menunjukkan bahwa indeks massa tubuh responden paling banyak berada dalam katagori normal $(41,4 \%)$.

Hasil analisis univariat karakteristik responden berdasarkan dukungan keluarga dapat dilihat pada tabel 4 berikut ini:

Tabel 4. Distribusi Karakteristik Responden Berdasarkan Dukungan Keluarga Di Poliklinik Syaraf RSUD Raden Mattaher Jambi Tahun $2018(n=70)$

\begin{tabular}{|c|c|c|}
\hline Dukungan Keluarga & Frekuensi & Persentase (\%) \\
\hline Disfungsi Sedang & 33 & $47,1 \%$ \\
\hline Baik & 37 & $52,9 \%$ \\
\hline Jumlah & 70 & $100 \%$ \\
\hline
\end{tabular}

Data tabel 4 menunjukkan bahwa dukungan keluarga responden paling banyak berada dalam katagori baik $(52,9 \%)$.

Hasil analisis univariat karakteristik responden berdasarkan status fungsional dapat dilihat pada tabel 5 berikut ini:

Tabel 5. Distribusi Karakteristik Responden Berdasarkan Status Fungsional Di Poliklinik Syaraf RSUD Raden Mattaher Jambi Tahun $2018(\mathrm{n}=70)$

\begin{tabular}{lcc}
\hline \multicolumn{1}{c}{ Status Fungsional } & Frekuensi & Persentase (\%) \\
\hline Ketergantungan Berat & 15 & $21,4 \%$ \\
Ketergantungan Sedang & 27 & $38,6 \%$ \\
Ketergantungan Ringan & 23 & $32,9 \%$ \\
Mandiri & 5 & $7,1 \%$ \\
\multicolumn{1}{c}{ Jumlah } & 70 & $100 \%$ \\
\hline
\end{tabular}

Data tabel 5 menunjukkan bahwa status fungsional responden paling banyak termasuk katagori ketergantungan sedang $(38,6 \%)$.

\section{Analisis Bivariat}

Analisis bivariat dilakukan untuk membuktikan hipotesis ada hubungan antara faktor nyeri, umur, indeks massa tubuh dan dukungan keluarga dengan status fungsional pasien osteoartritis.

Hasil analisis bivariat hubungan antara tingkat nyeri dengan status fungsional dapat dilihat pada tabel 6 berikut ini : 
Dewi Masyitah, Analisis Faktor-Faktor yang Berhubungan Dengan Status fungsional pada Pasien Osteoartritis di RSUD Raden Mattaher Jambi Tahun 2018

Tabel 6. Analisis Bivariat Hubungan Antara Nyeri Dengan Status Fungsional Di Poliklinik Syaraf RSUD Raden Mattaher Jambi Tahun $2018(\mathrm{n}=70)$

\section{Status Fungsional}

\begin{tabular}{|c|c|c|c|c|c|c|}
\hline \multicolumn{7}{|c|}{ Status Fungsional } \\
\hline Nyeri & $\begin{array}{c}\text { Ketergantungan } \\
\text { Berat }\end{array}$ & $\begin{array}{c}\text { Ketergantungan } \\
\text { Sedang }\end{array}$ & $\begin{array}{c}\text { Ketergantungan } \\
\text { Ringan }\end{array}$ & Mandiri & Total & p-value \\
\hline Ringan & $0(0.0 \%)$ & $2(22.2 \%)$ & $4(44.4 \%)$ & $3(33.3 \%)$ & $9(100 \%)$ & \\
\hline Sedang & $15(24.6 \%)$ & $25(41.0 \%)$ & $19(31.1 \%)$ & $2(3.3 \%)$ & $61(100 \%)$ & 0,04 \\
\hline Jumlah & $15(21.4 \%)$ & $27(38.6 \%)$ & $23(32.9 \%)$ & $5(7.1 \%)$ & $70(100 \%)$ & \\
\hline
\end{tabular}

Data tabel 6 menunjukkan bahwa hasil uji statistik hubungan variabel tingkat nyeri dengan status fungsional dengan menggunakan uji chi-square didapatkan nilai pvalue $=0,04(p<\alpha)$, maka dapat disimpulkan ada hubungan antara tingkat nyeri dengan status fungsional.
Hasil analisis bivariat hubungan antara umur dengan status fungsional dapat dilihat pada tabel 7 berikut ini:

Tabel 7. Analisis Bivariat Hubungan Antara Umur Dengan Status Fungsional Di Poliklinik Syaraf RSUD Raden Mattaher Jambi Tahun $2018(n=70)$

Status Fungsional

\begin{tabular}{|c|c|c|c|c|c|c|}
\hline Umur & $\begin{array}{c}\text { Ketergantungan } \\
\text { Berat }\end{array}$ & $\begin{array}{c}\text { Ketergantungan } \\
\text { Sedang }\end{array}$ & $\begin{array}{c}\text { Ketergantungan } \\
\text { Ringan }\end{array}$ & Mandiri & Total & p-value \\
\hline Dewasa Awal & $0(0 \%)$ & $1(14,3 \%)$ & $6(85,7 \%)$ & $0(0 \%)$ & $7(100 \%)$ & \multirow{4}{*}{0,02} \\
\hline Dewasa Menengah & $5(12,5 \%)$ & $16(40 \%)$ & $15(37,5 \%)$ & $4(10 \%)$ & $40(100 \%)$ & \\
\hline Dewasa Lanjut & $10(43,5 \%)$ & $10(43,5 \%)$ & $2(8,7 \%)$ & $1(4,3 \%)$ & $23(100 \%)$ & \\
\hline Jumlah & $15(21.4 \%)$ & $27(38.6 \%)$ & $23(32.9 \%)$ & $5(7.1 \%)$ & $70(100 \%)$ & \\
\hline
\end{tabular}

Data tabel 7 menunjukkan bahwa hasil uji statistik hubungan variabel umur dengan status fungsional dengan menggunakan uji chi-square didapatkan nilai $\mathrm{p}$ value $=0,02 \quad(\mathrm{p}<\alpha)$, maka dapat disimpulkan ada hubungan antara umur dengan status fungsional.
Hasil analisis bivariat hubungan antara indeks massa tubuh dengan status fungsional dapat dilihat pada tabel 8 berikut ini:

Tabel 8. Analisis Bivariat Hubungan Antara Indeks Massa Tubuh Dengan Status Fungsional Di Poliklinik Syaraf RSUD Raden Mattaher Jambi Tahun 2018 ( $\mathrm{n}=70)$

\begin{tabular}{|c|c|c|c|c|c|c|}
\hline Indeks Massa Tubuh & \multicolumn{4}{|c|}{ Status Fungsional } & Total & $\begin{array}{c}\text { p- } \\
\text { value }\end{array}$ \\
\hline Berat Badan Di Bawah Normal & $0(0 \%)$ & $1(50 \%)$ & $0(0 \%)$ & $1(50 \%)$ & $2(100 \%)$ & \\
\hline Kelebihan Berat Badan & $3(10,3 \%)$ & $4(26,7 \%)$ & $8(53,3 \%)$ & $0(0 \%)$ & $15(100 \%)$ & 0,02 \\
\hline Obesitas & $9(37,5 \%)$ & $13(54,2 \%)$ & $2(8,3 \%)$ & $0(0 \%)$ & $24(100 \%)$ & \\
\hline Jumlah & $15(21.4 \%)$ & $27(38.6 \%)$ & $23(32.9 \%)$ & $5(7.1 \%)$ & $70(100 \%)$ & \\
\hline
\end{tabular}

Data tabel 8 menunjukkan bahwa hasil uji statistik hubungan variabel indeks massa tubuh dengan status fungsional dengan menggunakan uji chi-square didapatkan nilai $\mathrm{p}$-value $=0,02(\mathrm{p}<\alpha)$, maka dapat disimpulkan ada hubungan antara indeks massa tubuh dengan status fungsional.

Hasil analisis bivariat hubungan antara dukungan keluarga dengan status fungsional dapat dilihat pada tabel 9 berikut ini:

Tabel 9. Analisis Bivariat Hubungan Antara Dukungan Keluarga Dengan Status Fungsional Di Poliklinik Syaraf RSUD Raden Mattaher Jambi Tahun $2018(\mathrm{n}=70)$

\begin{tabular}{|c|c|c|c|c|c|c|}
\hline \multirow[b]{2}{*}{$\begin{array}{c}\text { Dukungan } \\
\text { Keluarga }\end{array}$} & \multicolumn{4}{|c|}{ Status Fungsional } & \multirow[b]{2}{*}{ Total } & \multirow[b]{2}{*}{ p-value } \\
\hline & $\begin{array}{c}\text { Ketergantungan } \\
\text { Berat }\end{array}$ & $\begin{array}{c}\text { Ketergantungan } \\
\text { Sedang }\end{array}$ & $\begin{array}{c}\text { Ketergantungan } \\
\text { Ringan }\end{array}$ & Mandiri & & \\
\hline Disfungsi Sedang & $5(15,2 \%)$ & $10(30,3 \%)$ & $18(54,5 \%)$ & $0(0 \%)$ & $33(100 \%)$ & \\
\hline Baik & $10(27 \%)$ & $17(45,9 \%)$ & $5(13,5 \%)$ & $5(13,5 \%)$ & $37(100 \%)$ & 0,001 \\
\hline Jumlah & $15(21.4 \%)$ & $27(38.6 \%)$ & $23(32.9 \%)$ & $5(7.1 \%)$ & $70(100 \%)$ & \\
\hline
\end{tabular}

Data tabel 9 menunjukkan bahwa hasil uji statistik hubungan variabel dukungan keluarga dengan status fungsional dengan menggunakan uji chi-square didapatkan nilai $\mathrm{p}$-value $=0,001(\mathrm{p}<\alpha)$, maka dapat 
Dewi Masyitah, Analisis Faktor-Faktor yang Berhubungan Dengan Status fungsional pada Pasien Osteoartritis di RSUD Raden Mattaher Jambi Tahun 2018

disimpulkan ada hubungan antara dukungan keluarga dengan status fungsional.

\section{Pembahasan}

Pembahasan yang meliputi interpretasi dan diskusi hasil penelitian yang telah dijelaskan dengan mengacu pada teori dan penelitian yang sudah ada sebelumnya. Hasil uji statistik hubungan variabel tingkat nyeri dengan status fungsional dengan menggunakan uji chi-square didapatkan nilai $\mathrm{p}$-value $=0,04(\mathrm{p}<\alpha)$, maka dapat disimpulkan ada hubungan antara tingkat nyeri dengan status fungsional. Penelitian sebelumnya mengenai status fungsional pada kasus osteoartritis menunjukan hasil yang relatif sama bahwa antara persepsi nyeri terhadap status fungsional memiliki hubungan yang lemah dan bersifat negatif yang berarti bahwa semakin tinggi nyeri semakin rendah status fungsional (Njoto, 2017).

Osteoartritis merupakan kondisi penyakit yang kronis. Penyakit ini dapat menimbulkan kerusakan pada jaringan sekitar seperti otot, vaskuler, dan saraf. Keluhan nyeri yang dirasakan diakibatkan meningkatkan gaya friksi pada kedua permukaan sendi daripada proses inflamasi yang sedang terjadi. Pasien biasanya mengeluhkan nyeri yang dalam, diperburuk oleh adanya aktivitas, dan berkurang setelah istirahat (Nolte, 2013).

Nyeri dapat juga dirasakan selama istirahat ataupun saat malam hari dan hal tersebut diasosiasikan dengan progresifitas penyakit tingkat lanjut. Kekakuan sendi dapat terjadi jika pasien tidak melakukan aktivitas atau diam selama beberapa menit termasuk di dalamnya duduk lama dan tidur. Keadaan ini dapat terjadi dalam jangka waktu yang singkat, kurang dari 30 menit. Morning Stiffness pada umumnya hanya terjadi selama 5 - 10 menit setelah bangun tidur. Kekakuan yang dirasakan melebihi 30 menit menandakan adanya penyakit peradangan sendi seperti osteoartritis. Nyeri yang ditimbulkan osteoartritis adalah salah satu penyebab disabilitas dan menurunnya status fungsional pasien, berdampak pada terbatasnya aktifitas sehari-hari pasien misalnya berpakaian, menaiki tangga, bangun dari tempat tidur dan berjalan (Mahajan, A., Verma, S., \& Tandon, V. 2015).

Seseorang yang menderita nyeri akan mempengaruhi fisiologis dan kondisi emosional orang tersebut. Perubahan tersebut dapat berupa kecemasan dan menjadi mudah marah, menyebabkan denyut nadi cepat, frekuensi napas meningkat, gangguan pola tidur bahkan dapat mengganggu aktivitas sehari-hari. Penelitian menunjukkan bahwa ada hubungan antara nyeri dengan kemandirian dalam aktivitas kehidupan sehari-hari dimana semakin tinggi nyeri maka tingkat kemandirian akan berkurang. Hasil penelitian tersebut juga menunjukkan bahwa pasien osteoartritis yang mengalami nyeri dengan intenstas ringan maupun tinggi, sebagian besar mengalami penurunan kemampuan dalam kemandirian dalam melakukan aktivitas sehari-hari (Apriliyasari \& Wulan, 2016).

Komponen aktivitas kehidupan sehari-hari yang sebagian besar terganggu adalah beraktivitas diwaktu luang $(41 \%)$, menggunakan transportasi $(25.6 \%)$ dan beribadah $(12,8 \%)$, pasien harus dibantu dalam melakukan aktivitas tersebut. Hasil penelitian serupa dilakukan oleh Zivkovic, et all (2009) didapatkan hasil sebanyak $22 \%$ mengalami penurunan fungsi setiap harinya dan $41 \%$ mengalami ketidakmampuan fungsional seperti mandi, kebersihan diri, bangun, makan, berjalan, menangkap materi, menyerap dan beraktivitas (Apriliyasari \& Wulan, 2016).

Hasil uji statistik hubungan variabel umur dengan status fungsional dengan menggunakan uji chi-square didapatkan nilai $\mathrm{p}$-value $=0,02(\mathrm{p}<\alpha)$, maka dapat disimpulkan ada hubungan antara umur dengan status fungsional. Osteoathritis adalah penyakit bersifat kronik, berjalan progresif lambat, noninflamasi atau hanya menyebabkan inflamasi ringan, serta ditandai dengan adanya deteriorasi dan abrasi rawan sendi serta pembentukan tulang baru pada permukaan sendi. Terjadinya osteoartritis dipengaruhi oleh faktor-faktor resiko yaitu salah satunya adalah umur (proses penuaan). Usia lebih dari 60 tahun mempunyai kejadian paling banyak $49 \%$ menderita osteoarthritis dan kejadian paling sedikit pada usia $<50$ tahun sebesar $24 \%$. Usia merupakan faktor terkuat dibandingkan dengan faktor lain untuk terjadinya osteoathritis (Lubis, 2013).

Sejalan dengan bertambahnya umur maka terjadi penurunan fungsi tubuh mengakibatkan permasalahan gerak, fungsi berjalan, keseimbangan, penurunan kemampuan fungsional dan penurunan kemandirian dalam aktivitas kehidupan sehari-hari. Terjadi perubahan morfologis otot pada lansia dengan osteoartritis yang menyebabkan perubahan fungsional otot, yaitu terjadinya penurunan kekuatan otot, elastisitas dan fleksibilitas otot, kecepatan waktu reaksi dan rileksasi, dan kemampuan fungsional. Penurunan fungsi dan kekuatan otot akan mengakibatkan yaitu penurunan kemampuan mempertahankan keseimbangan tubuh, hambatan dalam gerak duduk ke berdiri, peningkatan resiko jatuh, perubahan postur (Frontera, et al, 2000).

Adanya perbedaan morfologis otot antara lansia (usia 70 - 81 tahun) dan orang dewasa (usia 27 - 42 tahun). Perbedaan morfologis tersebut meliputi masa otot, serabut otot, fascia dan kartilago sendi. Perbedaan morfologis otot dan sendi antara lansia dan orang dewasa berakibat penurunan kekuatan otot lansia. Penurunan kekuatan otot dan sendi akan mempengaruhi kemampuan fungsional lansia. Penurunan kemampuan fisik lansia berpengaruh terhadap kemampuan aktivitas kehidupan sehari-harinya terutama pada mobilitas (26,5\%), koordinasi (15\%), kebugaran $(14,7 \%)$, dan fleksibilitas (12\%) (Narici, et al, 2003). 
Hasil uji statistik hubungan variabel indeks massa tubuh dengan status fungsional dengan menggunakan uji chi-square didapatkan nilai $\mathrm{p}$-value $=0,02(\mathrm{p}<\alpha)$, maka dapat disimpulkan ada hubungan antara indeks massa tubuh dengan status fungsional. Berat badan yang berlebih merupakan suatu kondisi yang erat kaitannya dengan peningkatan risiko untuk timbulnya osteoartritis terutama pada sendi penopang tubuh, seperti lutut. Obesitas akan meningkatkan stress pada sendi penopang tubuh sehingga akan memberikan rasa nyeri. Penurunan berat badan akan mengurangi rasa nyeri. Sebuah penelitian terkait hubungan Indeks Masa Tubuh (IMT) dengan kejadian osteoarthritis lutut menunjukan hasil bahwa seseorang dengan IMT $>23$ (overweight) memiliki risiko 2000 kali lebih besar untuk terkena osteoartritis dibandingkan dengan orang yang memiliki IMT normal (Mutiwara, Najirman \& Afriwardi, 2016).

Penelitian di San Paulo, Brazil yang meneliti hubungan IMT dengan derajat osteoartritis lutut berdasarkan kriteria Kellgren dan Lawrence menunjukkan hasil hubungan yang signifikan antara peningkatan IMT dengan peningkatan derajat osteoatritis pada pemeriksaan radiologis. Sebuah penelitian di Kroasia menyebutkan bahwa obesitas meningkatkan derajat kerusakan osteoartritis lutut yang dilihat dari gambaran radiologisnya (Sanghi, Singh, Kumari \& Mishra, 2010).

Pasien osteoartritis dengan berat badan berlebih (IMT >23) menyebabkan stress abnormal pada sendi lutut. Stress abnormal menyebabkan terjadinya perubahan biofisika yang berupa fraktur jaringan kolagen dan degradasi proteoglikan. Adanya fraktur jaringan kolagen membentuk celah pada kartilago memungkinkan terisi cairan sinovial dan membentuk kista subkondral. Proliferasi pembuluh darah pada kartilago sendi yang terdegradasi akan membentuk osteofit pada permukaan sendi tersebut. Kista subkondral akan menekan sinusoid sumsum menyebabkan kongesti vena, atau karena rangsangan serpihan rawan sendi kemudian terjadi sinovitis sehingga tumbuh osteofit pada tepi sendi, perlekatan ligamen atau tendon dengan tulang. Dengan kata lain, faktor mekanik menjadi penyebab osteoartritis pada seseorang dengan berat badan berlebih (Koentjoro, 2010).

Pada orang berat badan berlebih, lemak intramuskulernya meningkat dapat menyebabkan kelemahan saat berdiri dan berjalan. Beban sendi berlebih dan kelemahan otot menyebabkan otot tidak mampu untuk menahan tekanan sehingga menimbulkan trauma tulang rawan sendi. Trauma ini akan menimbulkan keluhan nyeri dan menyebabkan kesulitan untuk berjalan. Keadaan ini akan menghambat dan mengurangi aktifitas sehari-harinya sehingga dapat terjadi pengecilan (atrofi) otot yang akan semakin memperparah kelemahan sendi (Mutiwara, Najirman \& Afriwardi, 2016).
Hasil uji statistik hubungan variabel dukungan keluarga dengan status fungsional dengan menggunakan uji chi-square didapatkan nilai $\mathrm{p}$-value $=0,001(\mathrm{p}<\alpha)$, maka dapat disimpulkan ada hubungan antara dukungan keluarga dengan status fungsional. Dukungan yang berarti untuk motivasi meningkatkan aktivitas fisik adalah dukungan dari keluarga atau orang terdekat, misalnya : pasangan, anak-anak, saudara kandung atau cucu. Namun peristiwa meninggalnya anggota keluarga atau kepindahan tempat tingga ke daerah lain dapat menyebabkan perubahan struktur keluarga. Dalam hal ini makan sangat penting keberadaan kelompok pendukung lain seperti : tetangga, teman dekat, kolega di tempat kerja atau organisasi (Jafar, Wiarsih \& Permatasari, 2011).

Dukungan keluarga dapat merupakan informasi verbal maupun nonverbal, saran, bantuan, atau tingkah laku yang diberikan oleh orang-orang terdekat berupa kehadiran serta hal-hal yang dapat memberi keuntungan emosional kepada penerimanya (Perry \& Potter, 2005). Masalah fisik yang sering membutuhkan bantuan terutama masalah sistem muskuloskeletal, masalah system kardiorespiratorik, masalah sistem sensoris, dan masalah pola tidur (Jafar, Wiarsih \& Permatasari, 2011).

Osteoartritis adalah salah satu masalah sistem muskuloskeletal yang sering terjadi. Dukungan keluarga sangat diperlukan dalam hal merawat anggota keluarga dengan osteoartritis. Keluarga merupakan sistem pendukung utama baik dalam keadaan sehat maupun sakit. Jika ada anggota keluarga yang sakit maka dukungan keluarga berupa menjaga dan merawat agar tetap dalam keadaan optimal dan produktif, mempertahankan dan meningkatkan status mental, mengantisipasi adanya perubahan sosial dan ekonomi, memotivasi dan memfasilitasi untuk memenuhi kebutuhan spiritual (Darwinto, 2013 dalam Ayuningtyas, 2019).

Dukungan keluarga dalam merawat penderita osteoartritis misalnya dengan mengingatkan tentang hal yang tidak boleh dilakukan seperti mengkonsumsi kacang-kacangan, aktivitas berlebih, dan menjaga agar berat badan normal dan ideal. Selain itu keluarga dapat memberikan kompres air hangat apabila penderita merasa nyeri sendi dan selalu memberikan dukungan psikososial terhadap penderita (Ayuningtyas, 2019).

\section{SIMPULAN}

1. Sebagian besar nyeri yang dialami oleh responden termasuk katagori nyeri sedang

2. Lebih dari separuh umur responden termasuk dalam rentang usia dewasa menengah

3. Indeks massa tubuh responden paling banyak berada dalam katagori normal

4. Dukungan keluarga responden paling banyak berada dalam katagori baik

5. Lebih dari separuh status fungsional responden 
Dewi Masyitah, Analisis Faktor-Faktor yang Berhubungan Dengan Status fungsional pada Pasien Osteoartritis di RSUD Raden Mattaher Jambi Tahun 2018

termasuk katagori ketergantungan sedang

6. Ada hubungan antara tingkat nyeri dengan status fungsional.

7. Ada hubungan antara umur dengan status fungsional.

8. Ada hubungan antara indeks massa tubuh dengan status fungsional.

9. Ada hubungan antara dukungan keluarga dengan status fungsional.

\section{DAFTAR PUSTAKA}

Apriliyasari, R.W., Wulan, E.S. (2016). Kemandirian Dalam Melakukan Aktivitas Sehari-Hari Pada Pasien Rheumatoid Atritis. Jurnal Keperawatan dan Kesehatan Masyarakat. 1(5) : 25-31.

Arikunto, S. (2002). Prosedur Penelitian: Suatu Pendekatan Praktek. Edisi revisi V. Jakarta: Rineka Cipta.

Arissa, M.I. (2012). Pola Distribusi Kasus Osteoartritis Di RSU Dokter Soedarso Pontianak Periode 1 Januari 2008 - 31 Desember 2009. Skripsi. Fakultas Kedokteran Universitas Tanjungpura Pontianak.

Ayuningtiyas, P.Y. (2019). Gambaran Peran Keluarga Dalam Merawat Anggota Keluarga Yang Mengalami Osteoartritis Di Desa Jetis. Skripsi. Fakultas Ilmu Kesehatan Universitas Muhammadiyah Surakarta.

Dahlan, M. S. (2009). Besar Sampel Dan Cara Pengambilan Sampel Dalam Penelitian Kedokteran Dan Kesehatan. Jakarta : Salemba Medika.

Dahlan, M. S. (2009). Statistik Untuk Kedokteran Dan Kesehatan. Jakarta : Salemba Medika.

Dochterman,J.M., Butcher, H.K., \& Bulechek,G.M. (2008). Nursing Intervention Classification (NIC).(5th ed). St.louis: Mosby.

Doenges, M. E,.(2001). Nursing Care Plans. Guidelines For Planning And Documenting Patient Care. Pennsylvania : Davis Company.

Frontera, W.R, Hughes, V.A, Fielding, R.A, Fiatarone, M.A, Evans, W.J, Roubenoff, R. (2000). Aging of Skeletal Muscle : a Longitudinal Study. Journal of Applied Physiologi, 88.

Hale, L.A., Waters, D., Herbison, P. (2012). A Randomized Controlled Trial To Investigate The Effects Of Water-Based Exercise To Improve Falls Risk And Physical Function In Older Adults With Lower-Extremity Osteoarthritis. Arch Phys Med Rehabil, 93: 27-34.

Ignatavicius, D, \& Workman,. (2006). Medical Surgical Nursing : Critical Thinking For Collaborative Care. 5th ed. St Louis, Missouri: Elsevier Inc.

Imayati, K. (2011). Laporan Kasus Osteoartritis. Bagian Ilmu Penyakit Dalam Fakultas Kedokteran Universitas Udayana Denpasar.

Jafar, N., Wiarsih, W. \& Permatasari, H. (2011).
Pengalaman Lanjut Usia Mendapatkan Dukungan Keluarga. Jurnal Keperawatan Indonesia. 14(3) : 157-164.

Koentjoro,S.L. (2010). Hubungan Antara Indeks Masa Tubuh (IMT) Dengan Derajat Oasteoartritis Lutut Menurut Kellgren Dan Lawrence. Skripsi. Fakultas Kedokteran Universitas Diponogoro.

Lee, J., Kim, J.H., Chung, E. and Lee, B.H. (2017). Functional State Of Knee Arthritis Patients And Related Factors. Journal of Physical Therapy Science. 29(2): 323-327.

Lubis, N. R., (2013). Osteoartritis. Jurnal Ilmu Bedah Indonesia, 41(1) : 19-27.

Mahajan, A., Verma, S., \& Tandon, V. (2015). Osteoarthritis. JAPI, 53 : 634-641. India : Government Medical College.

McKay, C., Prapavessis, H., Doherty, T. (2012). The Effect Of A Prehabilitation Exercise Program On Quadriceps Strength For Patients Undergoing Total Knee Arthroplasty: A Randomized Controlled Pilot Study. PM R, 2012, 4: 647-656.

Mutiwara, E., Najirman, dan Afriwardi. (2016). Hubungan Indeks Massa Tubuh dengan Derajat Kerusakan Sendi pada Pasien Osteoartritis Lutut di RSUP Dr. M. Djamil Padang. Jurnal Kesehatan Andalas. 5(2) : 376-380.

Narici, M.V, Maganaris, C.N, Reeves, N.D, Capodaglio, P. (2003). Effect of Aging on Human Muscle Architecture. Journal of Applied Physiologi 95.

Njoto. (2017). Epidemiologi, Patogenesis dan Faktor Resiko Osteoartritis. Surabaya : Fakultas Kedokteran Universitas Wijaya Kusuma

Nolte, K. (2013). Exercise Prescription In The Management Of Rheumatoid Arthritis. South African Family Practice, 55:4, 345-349. University of Pretoria

Potter, P.A., \& Perry, A.G. (2005). Fundamental Of Nursing: Study guide and skills performance checklists, 6th ed, Australia, Elseiver-Mosby.

Pratiwi, A.I. (2015). Diagnosis And Treatment Osteoarthritis. J Majority Vol. 4 No. 4 Februari 2015. Faculty of Medicine, University of Lampung.

Price, S.A., \& Wilson, M.L. (2003). Pathophysiology : Clinical Concepts of Disease Processes. New York : Mosby.

Ropyanto, C.B. (2011). Analisis Faktor-Faktor Yang Berhubungan Dengan Status Fungsional Pasien Paska Open Reduction Internal Fixation (ORIF) Fraktur Ekstremitas Bawah Di RS. Ortopedi Prof. Soeharso Surakarta. Tesis. Fakultas Ilmu Keperawatan Universitas Indonesia

Sanghi D, Singh A, Kumari R, Mishra R. (2010). The Association Of Anthropometric Measures And Osteoarthritis Knee. Clinics Sao Paulo.66(2):275279. 
Dewi Masyitah, Analisis Faktor-Faktor yang Berhubungan Dengan Status fungsional pada Pasien Osteoartritis di RSUD Raden Mattaher Jambi Tahun 2018

Smeltzer, S., \& Bare, B. (2009). Brunner and Suddarth's : Text Book Medical Surgical Nursing. St. Louis Missouri : Elsevier Saunders.

Soeroso J, Isbagio H, Kalim H, Broto R, Pramudiyo R. (2009). Osteoartritis. Buku Ajar Ilmu Penyakit Dalam. Edisi ke-5. Jakarta: Pusat Penerbitan Ilmu Penyakit Dalam. 